Trakya Üniversitesi

Eğitim Fakültesi Dergisi

XV. Uluslararası Katılımlı Sınıf Öğretmenliği

Eğitimi Sempozyumu (11-14 Mayıs 2016)

USOS 2016 Özel Sayısı, 97-113

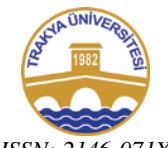

ISSN: 2146-071X
Trakya University

Journal of Education Faculty

XV. International Primary Teacher Education

Symposium (11-14 May 2016)

IPTES 2016 Special Issue, 97-113

Doi: $10.24315 /$ trkefd.366693

Geliș Tarihi: 21.11.2016

Yayına Kabul Tarihi: 27.07.2017

\title{
İlkokul Öğrencilerinin Çevre Kavramları İle İlgili Çizimlerinin Analizi ${ }^{1}$
}

\section{Analyze of the Drawings on Environmental Concepts of the Primary School Students}

\author{
Emre PINAR ${ }^{2}$, Mehmet YAKIŞAN ${ }^{3}$
}

\begin{abstract}
Öz: Bu çalışmanın amacı ilkokul öğrencilerinin çevre konusunda çizdikleri resimlerle çevreye yönelik algılarını belirlemektir. Bu amaçla Samsun İl merkezinde iki ilkokul çalışma için seçilmiş ve seçilen ilkokullardaki birinci sınıflardan 38, ikinci sinıflardan 64, üçüncü sınıflardan 59 ve dördüncü sınıflardan 50 olmak üzere toplam 211 öğrenci çalışmaya dahil edilmiştir. Çalışmada öğrencilerden, önce "Çevre kirliliği”" daha sonra da "Temiz çevre" kavramlarıyla ilgili ayrı ayrı resimler çizmeleri istenmiştir. Daha sonra her bir öğrenci ile yapılan görüşmeler ile çizdikleri resimleri açıklamaları ve "Sizce çevre kirliliği nedir?" "Çevre kirliliğine sebep olan faktörler nelerdir?" "Çevre kirliliği nasıl önlenebilir?" "Temiz bir çevre için neler yapmalıyız?" gibi soruları cevaplamaları istenmiştir. Öğrencilerin çizdikleri resimler görüşmelerdeki açıklamaları da dikkate alınarak analiz edilmiştir. Yapılan analizler sonucunda en yaygın çevre kirliliği olarak evsel atıklardan oluşan "çöp" kavramına tüm sınıflarda çizilen resimlerde yer verildiği görülmüştür. Bu çevre sorunu yanında hava kirliliğine ve bu iki soruna oranla daha az öğrencinin su kirliliği kapsamında deniz kirliliğine ilişkin çizimler yaptığı tespit edilmiştir. Diğer çevre sorunlarına resimlerde neredeyse hiç yer verilmemiştir. Öğrenciler temiz çevre kavramı hakkında çöplerin atılmadığı, akarsu, ağaç ve yeşilliğin olduğu çizimler yapmışlardır. Sonuç olarak ilkokul öğrencilerinin çevre kirliliği hakkında çok sınırlı bir bilgiye sahip oldukları, çevre kirliliğine çoğunlukla çöplerin sebep olduğunu ve çöplerin toplanmasıyla çevre kirliliğinin büyük oranda önlenebileceğini düşündükleri anlaşılmaktadır.
\end{abstract}

Anahtar sözcükler: Çevre kirliliği, temiz çevre, ilkokul ögrrencileri, çizim

\begin{abstract}
The aim of this study is to determine the perceptions of the primary school students on the environment through their drawings. Thus, two primary schools in Samsun centre were chosen for the study and totally 211 students of which 38 at first grade, 64 at second grade, 59 at third grade and 50 at fourth grade were included in the study. In the study, the students

\footnotetext{
1 Bu çalışmanın bir bölümü 11-14 Mayıs 2016 tarihinde Muğla Sıtkı Koçman Üniversitesi tarafindan düzenlenen XV. Uluslararası Sınıf Öğretmenliği Eğitimi Sempozyumu'nda sözlü bildiri olarak sunulmuştur.

219 Mayıs Üniversitesi, Eğitim Bilimleri Enstitüsü, Fen Bilgisi Eğitimi Bilim Dalı

319 Mayıs Üniversitesi, Eğitim Fakültesi, Biyoloji Eğitimi ABD, yakisan@omu.edu.tr
} 
were asked to draw on firstly "Environmental pollution" and then "Clean environment" separately. After that, each student was interviewed to hear their explanations on their drawings and they were asked questions like "What is the environmental pollution in your opinion?", "What are the factors causing environmental pollution?", "How can we prevent the environmental pollution?", and "What should we do for a clean environment?" The paintings of the students were analyzed with reference to their explanations in the interviews. As result of these analyses it was seen that all the paintings include the "domestic trash" causing environmental pollution in all grades. In addition to this environmental problem, it was found that air pollution and low number of students with compare to first two, considered the sea pollution within the scope of the water pollution. Other environmental problems had always never been referred in the drawings. The students made paintings on clean environment where there is no trash with rivers, trees and green. As a result, it is seen that the primary school students have very limited knowledge of environmental pollution; they think that the trashes are the main reason of the environmental pollution and the pollution can be prevented if the trashes are collected regularly.

Keywords: environmental pollution, clean environment, elementary school students, drawing

\section{GíRiş}

Doğada insanın var olduğu günden bu güne insanların doğaya hükmetme isteği hızla artmış ve bu da doğanın hızlı bir şekilde tahrip edilmesine yol açmıştır (Selvi, 2007). Özellikle son iki yüzyılda teknolojideki gelişmeler sayesinde insanın imkanlarının artması çevre sorunlarının hızla artmasını da beraberinde getirmiştir. Son yıllardaki hızlı nüfus artışı, sanayileşme, kentleşme ve doğal kaynakların bilinçsizce kullanılması gibi insanların çevreyi değiştirmeye yönelik aktiviteleri ekolojik dengeyi ve bunun sonucunda tüm insanlığ çevre sorunlarının yaşanmasına neden olmuştur (Akbaş, 2007; Yıldız, Sipahioğlu ve Yılmaz, 2000). Çevre sorunları başta insan olmak üzere tüm canlıları tehdit etmektedir. Günümüzde başta küresel 1sınma olmak üzere ozon tabakasının incelmesi, kutuplarda buzulların hızla erimesi, iklim değişikliği gibi çevresel sorunların üstesinden gelmek için tüm dünya seferber olmuştur. Dünyada küresel bazda yapılan iklim ve çevre toplantılarından da anlaşılacağı üzere çevre sorunları yerel olmaktan çok küresel bir problemdir (Erten, 2005). Çevre sorunlarının üstesinden gelmenin en kestirme yolu bu çevre sorunlarına en fazla katkı yapan insanı çevre sorunları konusunda bilinçlendirmektir. İnsanların çevreyi kirleten ve çevre sorunlarına neden olan yaşam biçimlerinde önemli değişikliler meydana getirilmediği sürece dünyayı tehdit eden çevre sorunlarının çözülemeyeceği genel kabul görmektedir (Selvi, 2007). Bu nedenle her yaştaki insana formal ya da informal olarak çevre eğitimi verilmesi gerekmektedir.

MEB, (2009) İlköğretim 1, 2 ve 3. Sınıflar Hayat Bilgisi Dersi Öğretim Programının vizyonunda öğrencilerin "Kendisiyle, toplumsal çevresiyle ve doğa ile barışık" olmaları hedeflenmektedir. Programda öğrencilere kazandırılacak temel beceriler arasında yer alan "Kaynakları Etkili Kullanma" kapsamında ögrencilerin "Çevre bilinci geliştirme ve çevredeki kaynakları etkili kullanma" 
becerisini kazanmaları hedeflenmektedir. Bu becerilerin alt kazanımları olarak öğrencilerin "Yaşadiğı çevre ile bir bütün olduğunu fark etme" "İnsanla çevre arasındaki karşılıklı etkileşimi görme", "Çevreye zarar vermenin kendine zarar vermek olduğunu kavrama" gibi çevreye yönelik kazanımlar yer almaktadır. Ayrıca "Bilimin Temel Kavramlarını Tanıma" temel becerisi içerisinde "Ínsan, hayvan ve bitkilerin birbirlerini etkilediğini; bitkilerle hayvanların birbirlerini etkilediğini; insan, hayvan ve bitkilerin de fiziksel çevreyi etkilediğini fark etme" gibi çevreye yönelik kazanımlarla öğrencilerin çevre bilincini geliştirmek amaçlanmaktadır.

MEB, (2013) Fen Bilimleri Dersi Öğretim Programında ise “Birey, çevre ve toplum arasındaki karşılıklı etkileşimi fark etmek ve toplum, ekonomi, doğal kaynaklara ilişkin sürdürülebilir kalkınma bilincini geliştirmek" ana amaçları arasında yer almaktadır.

Bu doğrultuda 3. Sınıfta "Canlılar Dünyasına Yolculuk/Canlılar ve Hayat" ünitesiyle öğrencilerin; "...yaşadıkları çevreyi tanımaları, temiz tutmaları, korumaları ve sevmeleri, doğal ve yapay çevreyi gözlemleyerek örneklerle açıklamaları, kaynak kullanımında tutumluluk, tasarruf bilinci kazanmaları ve bireysel sorumluluk almalarl, ayrıca sağllkl yaşam bilinci kazanmaları" amaçlanmaktadır. Bu ünitede çevre temizliği, Doğal - yapay çevre ve Bilinçli tüketici kavramlarına yer verilmektedir.

Aynı şekilde 4. Sınıfta yer alan "Geçmişten Günümüze Aydınlatma ve Ses Teknolojileri / Fiziksel Olaylar" ünitesiyle öğrencilerin; "İnsanoğlunun, ses ve aydınlatma ile ilgili çevre, toplum ve insanı etkileyen çeşitli teknolojiler geliştirmekte olduğunu bilmeleri; ışı̆̆ın ve sesin uygun kullanılmadiğında insan hayatını olumsuz yönde etkilediğini kavramaları ve bu duruma çözümler üretmeleri" amaçlanmaktadır. Işık ve ses kirliliği kavramlarına yer verilmektedir.

Fen bilimleri 4. Sınıftaki "Mikroskobik Canlılar ve Çevremiz / Canlılar ve Hayat” ünitesiyle de öğrencilerin; “...insan ve çevre etkileşiminin önemini kavrayarak çevreyi temiz tutmanın, çevre kirliliğini önlemenin ve çevreyi güzelleştirmenin önemine yönelik bilgi ve beceriler kazanmaları" hedeflenmektedir. Bu ünitede de Çevre kirliliği, çevreyi koruma ve güzelleştirme kavramlarına yer verilmektedir.

Dikkat edilecek olursa MEB tarafından hazırlanan Hayat Bilgisi ve Fen Bilimleri öğretim programıyla öğrencilere yaşadığı çevrenin bir parçası olduğu, çevresiyle etkileşiminin sonuçlarını fark etmesi, çevresine zarar vermemesi, teknolojik gelişmeler neticesinde meydana gelen çevre sorunların nedenleri ve sonuçları doğrultusunda bilinçlenmesi, topluma ve çevreye karşı duyarlı olması amaçlanmaktadır. Bu noktada ilkokulda verilen çevre eğitiminin öğrencilerde ne tür bir çevre algısı oluşturduğunu tespit etmek, yapılan öğretimi gözden geçirmek açısından önem arz etmektedir. Ayrıca formal öğretimin başında ilkokulda öğrencilere doğru ve yeterli bir çevre algısının kazandırılması daha sonraki öğrenim hayatını da etkileyecektir. Bu çalışmanın amacı ilkokul öğrencilerinin çevre konusunda çizdikleri resimlerle çevreye yönelik algılarını belirlemektir.

\section{YÖNTEM}

$\mathrm{Bu}$ çalışmanın amacı ilkokul öğrencilerinin çevre konusunda çizdikleri resimlerle çevreye yönelik algılarını belirlemektir. Bu amaç için var olan bir olay 
ya da durumu var olduğu şekliyle betimlemeyi amaçlayan tarama modeli (Karasar, 2008) kullanılarak betimsel bir çalışma gerçekleştirilmiştir. İlkokul 1, 2, 3 ve 4. Sınıf öğrencilerinin çevreye yönelik algılarının nasıl olduğunu belirlemek amacıyla zamansal tarama yaklaşımlarından, gelişimin, çeşitli gelişmişlik evrelerini temsil ettiği kabul edilen, birbirinden ayrı gruplar üzerinde ve bir anda yapılacak çalışmalarla belirlemeyi amaçlayan kesit alma yaklaşımı kullanılmıştır.

\section{1. Çalışma Grubu}

Çalışma 2015-2016 öğretim yılı güz döneminde Samsun il merkezdeki iki ilkokulda Gazipaşa İlkokulu ve Necatibey İlkokulunda yapılmışıı. Uygulama için Milli Eğitim Bakanlığından gerekli izinler alınmıştır. Bu ilkokullarda öğrenim gören birinci sınıflardan 38, ikinci sinıflardan 64 , üçüncü sinıflardan 59 ve dördüncü sınıflardan 50 olmak üzere toplam 211 öğrenci çalışmaya dahil edilmiştir. Araştırmanın yürütüldüğü iki ilkokul ve bu okul içerisindeki öğrencilerin seçiminde uygun örnekleme yöntemi kullanılmıştır.

\subsection{Verilerin Toplanması}

İlkokul öğrencilerinin çevreye yönelik algılarını belirlemek için çizim yapmaları ve çizimlerini anlatmaları istenmiştir. Zira birçok çalışmada çocukların (çevreye algılarına ait) imgelerini analiz etmede yaptıkları çizimler güçlü bir araç olarak görülmektedir (Rodari, 2007). Yaptırılan çizimler aracılığıyla çocukların iç dünyasına yönelik bilgiyi görsel bir yapı içerisinde tanımlamanın, duygularını anlamanın, gerçek düşüncelerini, arzu ve isteklerini belirlemenin mümkün olabileceği belirtilmektedir (Özsoy ve Ahi, 2014; Piperno, Di Biasi ve Levi, 2007; Leonard, 2006). Ayrıca çocukların en çok resim yaparken eğlendiklerini ve araştırmacı ile daha yakın bir iletişim kurduklarını göstermektedir. (Özsoy ve Ahi, 2014). Ancak öğrencilerin imgelerinin belirlenmesinde tek başına çizimlerin yetersiz olduğu ve çizimlerin yanında öğrencilerin mutlaka çizimlerini anlatmalarını sağlayacak görüşmelerin yapılması gerektiği vurgulanmaktadır (Ersoy ve Türkkan, 2009; Ersoy ve Türkkan, 2010). Çalışmada öğrencilere öncelikle "Çevre kirliliği" kavramı ifade edildiğinde zihinlerinde canlanan kirli çevre imgesini çizmeleri istenmiştir. Çevre kirliliği ile ilgili çizimlerini bitirdikten sonra "Temiz çevre" kavramıyla ilgili çizimler yapmaları istenmiştir. Öğrencilerin çevreye yönelik yapacakları çizimler için 1 ders saati süre verilmiş ve iki aşamada çizim yapmaları sağlanmıştır. Öğrenciler bu amaç için resim kâğıtları dağıtılmış ve resimlerini boya kullanarak çizmeleri istenmiştir. Öğrencilere her iki çizimi bitirdikten sonra her bir öğrenci ile yapılan görüşmeler ile çizdikleri resimleri açılamaları için her bir öğrenci için genel olarak 2-3 dakika süre ayrılmıştır. Öğrenciler öncelikle yaptıkları çizimleri anlatmaları istenmiştir. Öğrencilerin anlatımlarına göre "Sizce çevre kirliliği nedir?" "Çevre kirliliğine sebep olan faktörler nelerdir?" "Çevre kirliliği nasıl önlenebilir?" "Temiz bir çevre için neler yapmalıyız?" gibi soruları cevaplamaları istenmiş̧ir. Öğrenci anlatımları kayıt altına alınmıştır. Çizim sırasında sınıf öğretmeni ve araştırmacı sınıfta hazır bulunmuştur. Öğrencilere hiçbir yönlendirme olmadan çevreye yönelik düşünce ve algılarını özgür bir şekilde çizim ve anlatımlarına yansıtmalarına firsat verilmiştir.

\subsection{Verilerin Analizi}


Öğrencilerin çizdikleri resimler görüşmelerdeki açıklamaları da dikkate alınarak analiz edilmiştir. Her bir öğrencinin çizimleri ayrı ayrı analiz edilmiştir. Analizler sırasında temiz ve kirli çevre ile ilgili çizimler ayrı analiz edilmiştir. Öğrencilerin çizimleri içerisinde ortak olan kavramlar tespit edilerek kategorize edilmiştir. Temiz ve kirli çevre için tespit edilen ortak kavramların 1, 2, 3, ve 4. sınıflardaki öğrenci çizimlerindeki frekansları belirlenmiş ve tablo haline getirilmiştir. Öğrencilerin çizimlerinde tespit edilen öğeleri en iyi yansıtan çizimlere yer verilerek yorumlanmıştır.

\section{BULGULAR}

İlkokul öğrencilerinin çevre kirliliği ve temiz çevre kavramları hakkındaki çizimleri ve bu çizimlerle ilgili açıklamalarından elde edilen veriler analiz edilmiş ve Tablo 1 halinde düzenlemiştir.

Tablo 1. İlkokul öğrencilerinin çevre kirliliği ve temiz çevre ile ilgili çizimlerinde yer alan kavramların sınıflara gore dağılımı

\begin{tabular}{|c|c|c|c|c|c|c|c|c|}
\hline \multirow{2}{*}{ Kavramlar } & \multicolumn{2}{|c|}{ 1.Sinif } & \multicolumn{2}{|c|}{ 2.Sinıf } & \multicolumn{2}{|c|}{ 3.Sinıf } & \multicolumn{2}{|c|}{ 4.Sinıf } \\
\hline & f & $\%$ & $\mathbf{f}$ & $\%$ & $\mathbf{f}$ & $\%$ & $\mathbf{f}$ & $\%$ \\
\hline Çöp & 36 & 94,7 & 58 & 92 & 57 & 96,6 & 45 & $\overline{90,0}$ \\
\hline Çevreye Çöp Atmama & 31 & 81,6 & 57 & 90,4 & 57 & 96,6 & 45 & 90,0 \\
\hline Doğal Çevre & 34 & 89,5 & 61 & 96,8 & 55 & 93,2 & 48 & 96,0 \\
\hline Hava Kirliliği & 12 & 31,6 & 10 & 15,9 & 14 & 23,7 & 16 & 32,0 \\
\hline Duman & 6 & 15,8 & 5 & 7,9 & 11 & 18,6 & 10 & 20,0 \\
\hline Oksijen & 6 & 15,8 & 0 & 0,0 & 0 & 0,0 & 1 & 2,0 \\
\hline Egzoz Dumanı & 4 & 10,5 & 2 & 3,2 & 8 & 13,6 & 9 & 18,0 \\
\hline Bitki ve Hayvanlara Saygı & 4 & 10,5 & 4 & 6,3 & 6 & 10,2 & 9 & 18,0 \\
\hline Deniz Kirliliğgi & 4 & 10,5 & 0 & 0,0 & 5 & 8,5 & 6 & 12,0 \\
\hline Su Kirliliği & 4 & 10,5 & 0 & 0,0 & 9 & 15,3 & 5 & 10,0 \\
\hline Plastik & 3 & 7,9 & 7 & 11,1 & 6 & 10,2 & 2 & 4,0 \\
\hline Kâğ1t & 3 & 7,9 & 6 & 9,5 & 2 & 3,4 & 4 & 8,0 \\
\hline Çevre Bilinci & 3 & 7,9 & 0 & 0,0 & 12 & 20,3 & 9 & 18,0 \\
\hline Yiyecek & 2 & 5,3 & 1 & 1,6 & 12 & 20,3 & 2 & 4,0 \\
\hline Pet Şişe & 2 & 5,3 & 5 & 7,9 & 9 & 15,3 & 3 & 6,0 \\
\hline Cam & 2 & 5,3 & 4 & 6,3 & 5 & 8,5 & 5 & 10,0 \\
\hline Atık & 1 & 2,6 & 1 & 1,6 & 1 & 1,7 & 0 & 0,0 \\
\hline Petrol & 1 & 2,6 & 0 & 0,0 & 1 & 1,7 & 1 & 2,0 \\
\hline Ağaç Dikme & 1 & 2,6 & 0 & 0,0 & 1 & 1,7 & 2 & 4,0 \\
\hline Hava & 1 & 2,6 & 1 & 1,6 & 0 & 0,0 & 0 & 0,0 \\
\hline Yağmur & 1 & 2,6 & 0 & 0,0 & 0 & 0,0 & 1 & 2,0 \\
\hline Yapay Çevre & 0 & 0,0 & 0 & 0,0 & 4 & 6,8 & 0 & 0,0 \\
\hline Geri Dönüşüm & 0 & 0,0 & 3 & 4,8 & 1 & 1,7 & 0 & 0,0 \\
\hline Yanardağ & 0 & 0,0 & 1 & 1,6 & 0 & 0,0 & 0 & 0,0 \\
\hline Deprem & 0 & 0,0 & 2 & 3,2 & 0 & 0,0 & 0 & 0,0 \\
\hline Alışveriş & 0 & 0,0 & 1 & 1,6 & 0 & 0,0 & 0 & 0,0 \\
\hline Işık Kirliliği & 0 & 0,0 & 0 & 0,0 & 1 & 1,7 & 0 & 0,0 \\
\hline Akarsu & 0 & 0,0 & 0 & 0,0 & 0 & 0,0 & 1 & 2,0 \\
\hline Çöp Torbası & 0 & 0,0 & 0 & 0,0 & 1 & 1,7 & 0 & 0,0 \\
\hline Orman & 0 & 0,0 & 0 & 0,0 & 1 & 1,7 & 2 & 4,0 \\
\hline
\end{tabular}

İlkokul öğrencilerine çevre kirliliği ve temiz çevre kavramı ile ilgili resim çizmeleri ve çizdikleri resimleri açıklamaları istenmiştir. Öğrencilerin çizimlerinde geçen kavramlar ile ilgili Tablo 1 incelendiğinde ilkokulun tüm 
sınıflarında en fazla çöp kavramının çizildiği tespit edilmiştir. Tüm sınıflardaki öğrencilerin çok büyük bir kısmı (\%90'nın üstünde) çevre kirliliği kavramı ile ilgili çizimlerinde çöp kavramına yer vermişlerdir. Çöp olarak öğrencilerin büyük kısmı ayrı bir nitelendirme yapmadan "çöp" diye ifade ederlerken, bazı öğrenciler, çöp kavramını plastik, kağıt, yiyecek, pet şişe, cam ve atık olarak nitelendirdikleri tespit edilmiştir. Tüm sınıflardaki öğrencilerin çok büyük bir kısmı çevreyi kirleten en önemli faktörün daha çok evsel atıklar olarak nitelendirebileceğimiz çöp olduğu algısına sahip oldukları anlaşılmaktadır. Öğrencilerin çizimlerinde çevreyi kirleten ikinci faktör olarak, ev, fabrika bacalarından ve araba egzozlarından çıkan dumanların oluşturduğu hava kirliliğine yer verdikleri görülmektedir. Çöp ve hava kirliliğine oranla daha az sayıdaki öğrencinin ise çevre kirliliği kavramıyla ilgili olarak su ve deniz kirliliğine çizimlerinde yer verdikleri belirlenmiştir. Öğrencilerden (3. Sınıf öğrencisi) sadece 1'i çevre kirliliği olarak çiziminde 1 ş1k kirliliğine yer verdiği tespit edilmiştir.

Öğrencilerin çok büyük bir kısmının temiz çevre ile ilgili olarak "çevreye çöpleri atmama" başka bir ifadeyle çöplerin çöp kutusuna atılmasıyla çevrenin temiz olacağına yönelik algılarının olduğu tespit edilmiştir. İlkokulun tüm sınıflarındaki öğrencilerin çok büyük bir kısmı (\%90'nın üstünde) temiz çevre olarak "doğal çevre" olarak nitelendireceğimiz ağaçların, hayvanların, çiçeklerin olduğu gökyüzünde kuşların uçtuğu, suda balıkların yüzdüğü renkli resimler çizmişlerdir. Bunun yanında temiz çevre kavramıla ilgili çizimlerinde "Bitki ve hayvanlara saygılı olma" "ağaç dikme" ve "çevre bilincine sahip olma" gibi kavramlara yer verdikleri tespit edilmiştir. Öğrenciler arasından çok azı çizimlerinde geri dönüşüm ile ilgili öğelere yer verdikleri tespit edilmiştir.

Öğrencilerin çevre kirliliği ile ilgili çizdikleri resimlere örnekler aşağıda yer verilmektedir.

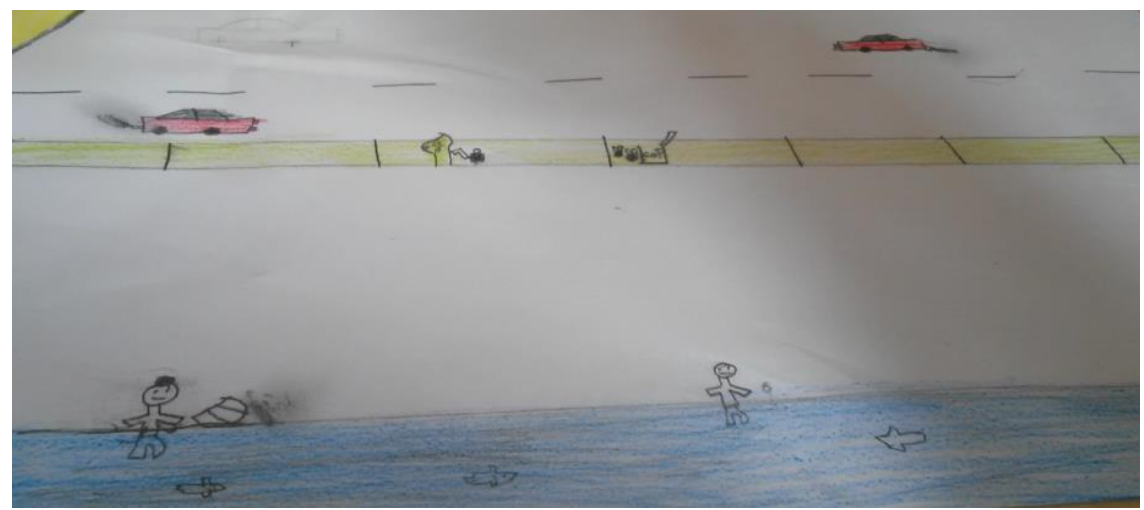

Çizim 1: İlkokul 4. Sınıf öğrencisinin çevre kirliliği ile ilgili çizdiği resim

Çizim 1'de görülen 4.sınıf öğrencisinin yaptığı resimde arabaların egzozlarının hava kirliliğine ve denizdeki çöplerin de su kirliliğine neden olduğu bir çevre çizilmiş̧ir. Öğrenciden çizimini anlatması istendiğinde öğrenci; "Adam petrolü yere döküyor balıklar da ölüyor. Adam elindekini yiyip yiyip atıyor" şeklinde ifade etmiştir. Aynı öğrenci çevre kirliliğini "ağaçları kesmek, yerlere çöpleri atmak" temiz çevreyi ise "insanların çöp atmamasl, arabaların egzoz 
çıkarmaması" şeklinde açıklarken çevre kirliliğini önlemek için de “ buraya (deniz kenarını parmağılla göstererek) yasaktır işareti koymalıyı ve insanlara söylemeliyiz” şeklinde ifade etmiştir.

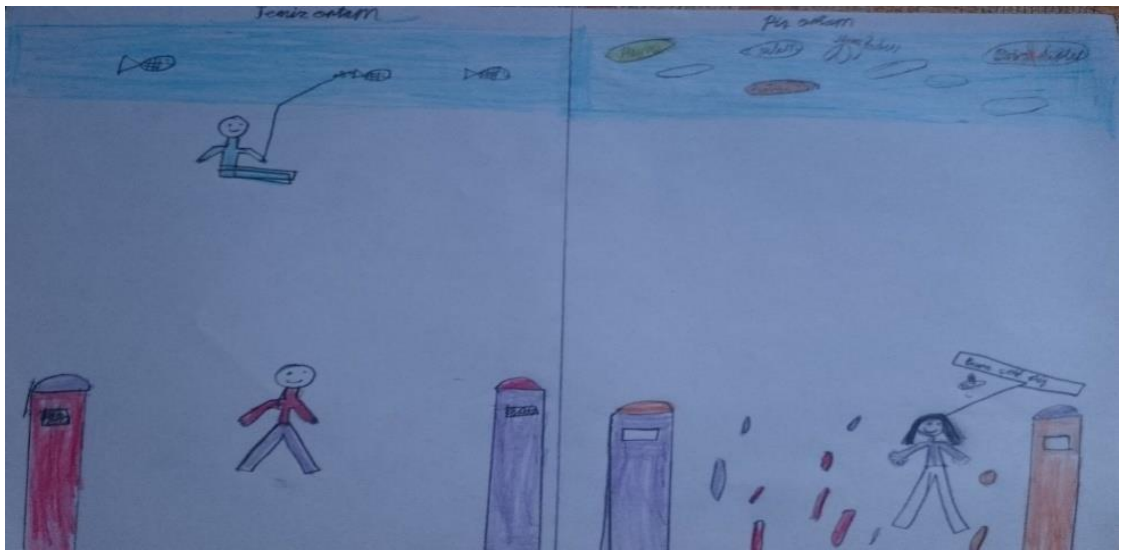

Çizim 2: İlkokul 3. Sınıf öğrencisinin çevre kirliliği ve temiz çevre kavramı ile ilgili çizdiği resim

Öğrencilerin çizimleri incelendiğinde tüm sınıflarda çevre kirliliğine neden olan en önemli faktör olarak çöp kavramı çizilmektedir. Çizim 2'de 3. sınıftan bir öğrenci çevre kirliliğini "Pis Ortam” olarak nitelendirmekte ve çöp kutusu yerine yere ve denize atılan çöplerin yerleri ve denizi kirlettiğini tasvir eden bir resim çizmektedir. Aynı öğrenci temiz çevreyi ise "Temiz Ortam" olarak nitelendirmekte çöpler çöp kutusuna atılmış ve temiz ortamdaki denizden bir kişi balık avlamakta olarak çizmiştir. Öğrenciler tarafından sıkça belirtilen çöp sorununa karşı bu çizimi yapan 3.sınıf öğrencisinin çözüm önerisi ise "Herkesi uyarırız, diyebiliriz ki lütfen çöpleri çöp kutusuna atın buralar kirleniyor” ş̧eklinde olmuştur. Ayrıca öğrenci çevreye atılarak çevre kirliliğine neden olan çöplerin yiyecek ve kağıtlar olduğunu belirtmiştir.

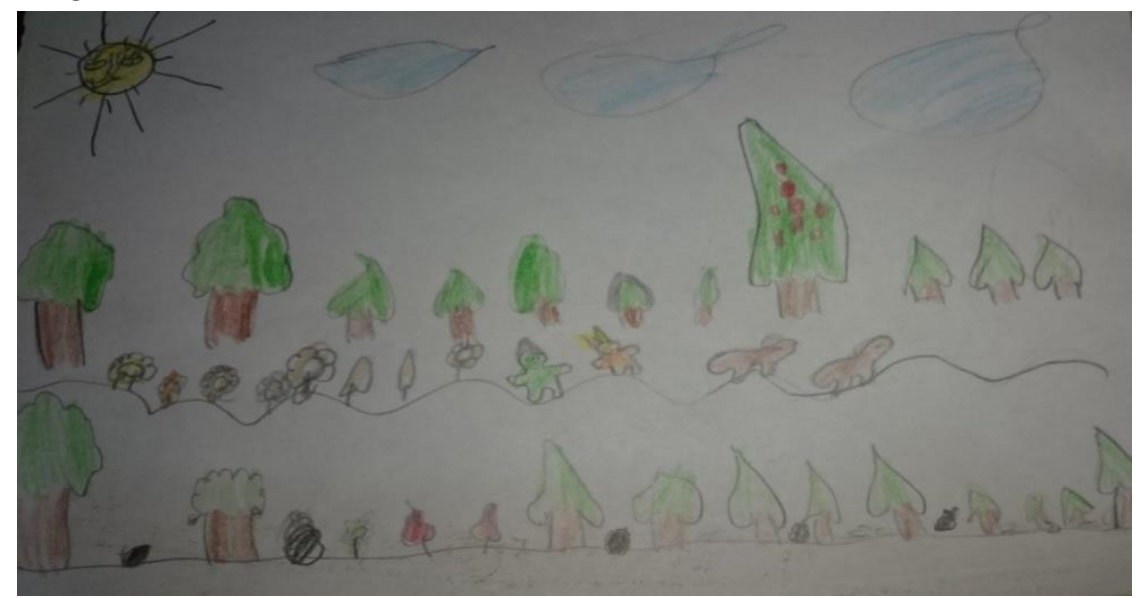

Çizim 3: İlkokul 2. Sınıf öğrencisinin çevre kirliliği ve temiz çevre ile ilgili çizdiği resim 
Çizim 3’te görüldüğü üzere 2. sınıf öğrencisi doğal çevrede ağaçlar, çiçekler ve hayvanların iç içe yaşadığı yeri temiz çevre olarak, aynı ortamda çöplerin artmasıyla birlikte çiçeklerin azaldığı ağaçların daha az geliştiği ve hayvanların yaşamadığı yeri de kirli çevre olarak (kağıdın alt kısmında) resmetmiştir. Ancak burada öğrenci resimde göstermemesine rağmen kirli çevre hakkında "Aklıma deprem geliyor. Her yer çöp olursa gidecek yerimiz kalmaz" şeklinde açıklama yapmıştır. Burada öğrenci çevre kirliliğini depremle ilişkilendirmektedir.

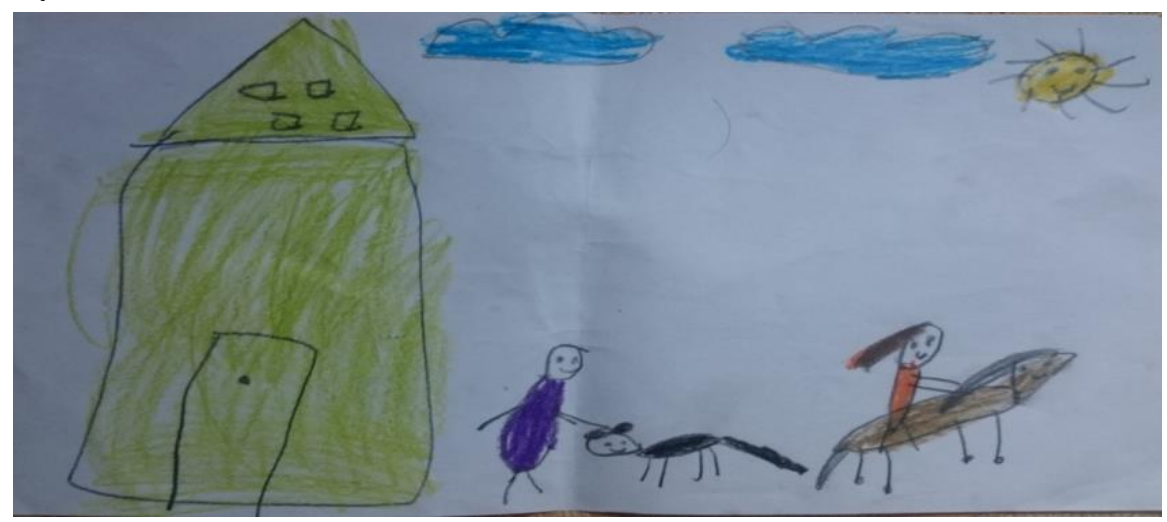

Çizim 4: İlkokul 1. Sınıf öğrencisinin temiz çevre kavramı hakkındaki çizdiği resim

Çizim 4'teki çizimi yapan 1.sınıf öğrencisi doğal bir çevrede çöplerden dolayı çevrenin kirlendiğini ifade ederken temiz çevre kavramı için çizdiği resimde "Hayvanları severek bir arada yaşadı̆̆ımı bir ortam" olarak ifade etmiştir. Zira öğrenci temiz çevre kavramı ile ilgili çizimini "Bir tane abi köpeğini seviyor, bir tane kiz da ata biniyor" şeklinde anlatmıştır.

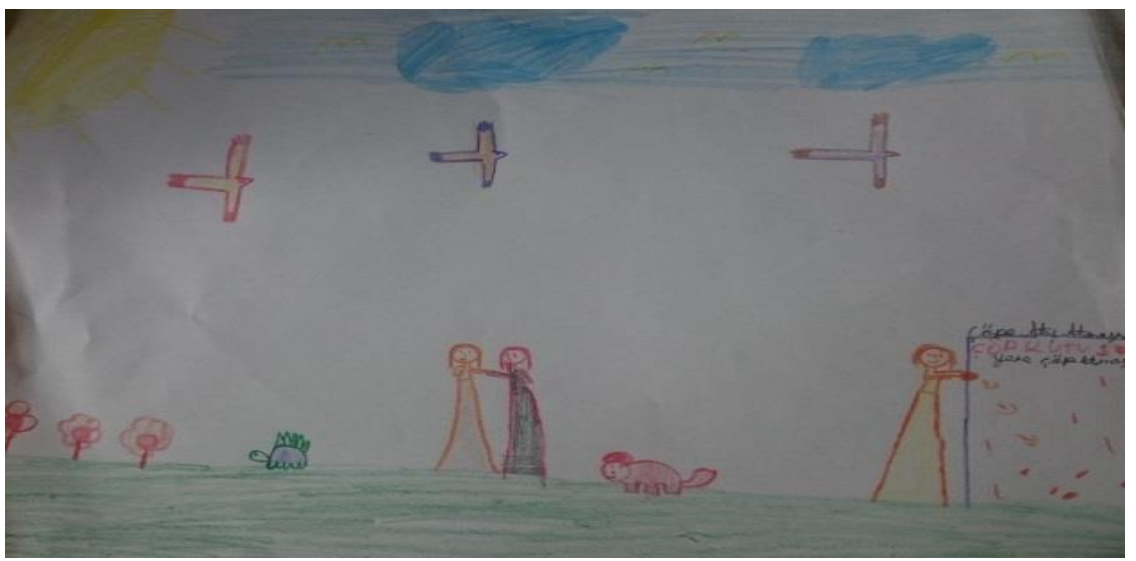

Çizim 5: İlkokul 3. Sınıf öğrencisinin temiz çevre kavramı ile ilgili çizdiği resim

Çizim 5'te görüldüğü gibi öğrenci temiz çevre olarak daha renkli bir resim çizmiştir. Temiz çevre adına çizilen resimde çöpler çöp kutusuna atılmakta, güneş 
ve mavi bulutların olduğu bir gökyüzünde farklı ve çok sayıda kuşlar uçmakta, yerde farklı çiçekler ve hayvanlar bulunmakta ve insanlar mutlu bir şekilde birbiriyle oynamakta oldukları bir ortam olarak tasvir edilmektedir.

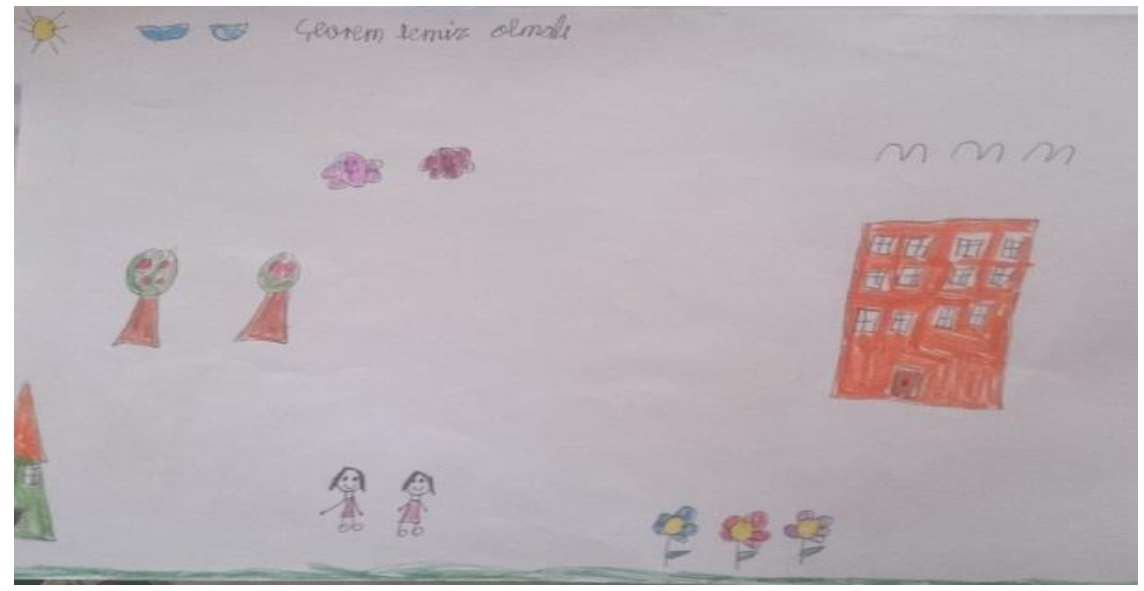

Çizim 6: İlkokul 2. Sınıf öğrencisinin temiz çevre kavramı ile ilgili çizdiği resim

Çizim 6'da 2. Sınıf öğrencisi temiz çevre olarak renkli bir resim çizmiştir. Resimde "Çevrem Temiz Olmalı" yazısı dikkat çekmekte ve gökyüzünde güneş ve mavi renkli bulutlar, havada uçan kuş ve renkli kelebekler bulunmaktadır. Yerde ise çocuklar oynamakta, yeşilliğin içinde rengarenk çiçek ve ağaçlar çevreyi süslemektedir. Ayrıca evde renkli bir şekilde çizilmiştir.

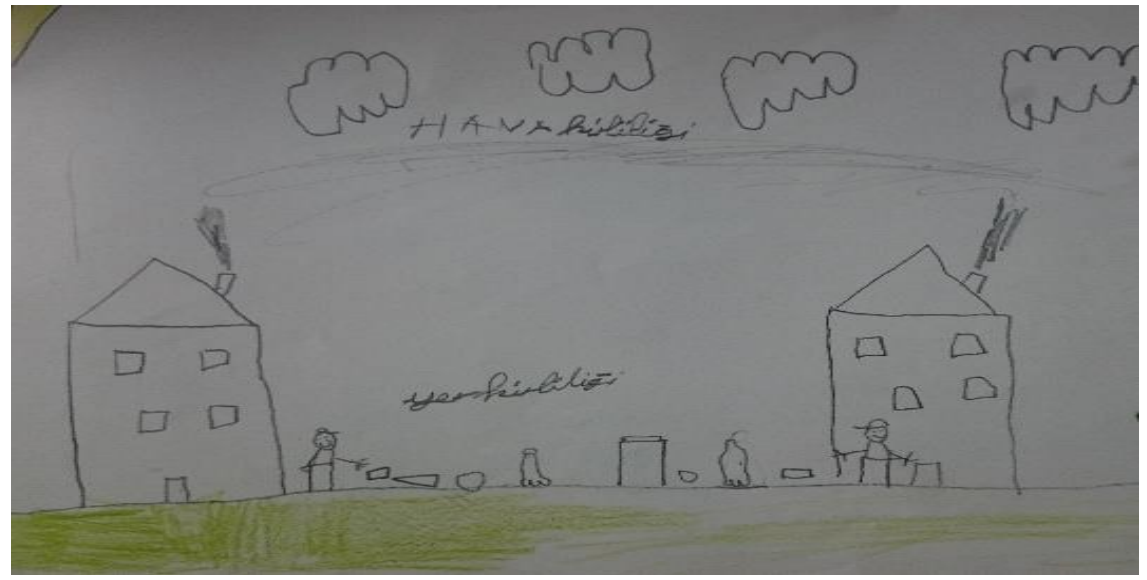

Çizim 7: İlkokul 4. sınıf öğrencisinin çevre kirliliği kavramı ile ilgili çizdiği resim

Çizim 5 ve 6'da temiz çevre ile ilgili çizimlerin aksine öğrenciler Çizim 7'da olduğu gibi kirli çevre olarak ise daha renksiz resimler çizmektedir. Evlerin bacalarından çıkan dumanlarla hava kirliliğinin olduğu ve insanlar tarafından atılan farklı çöplerle "Yer Kirliliğinin" olduğu bir ortam olarak betimlendiği görülmektedir. 


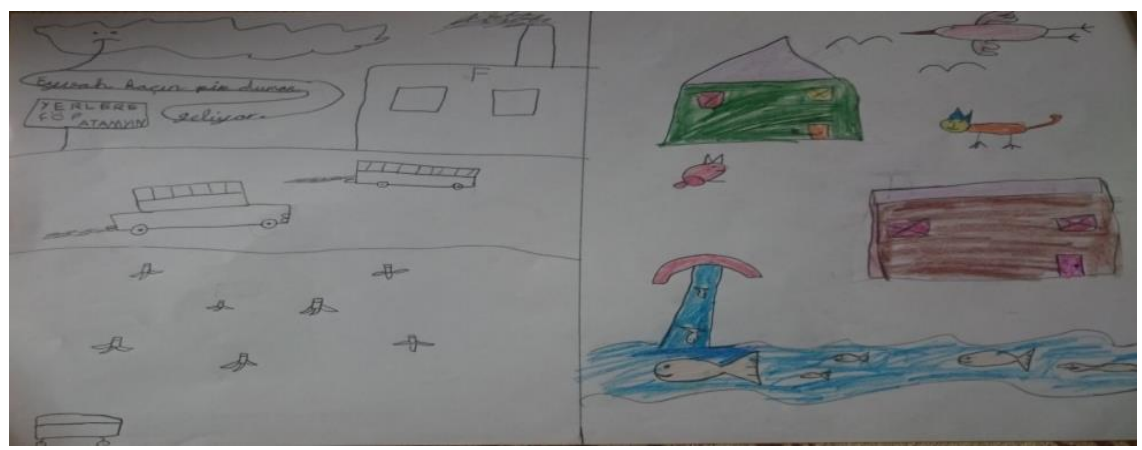

Çizim 8: İlkokul 3. Sınıf öğrencisinin temiz ve kirli çevre kavramları ile ilgili çizdiği resim

Çizim 8'deki 3. sınıf öğrencisinin çizimi incelenecek olursa kirli çevreyi ağaçların kesilmiş olduğu, fabrika bacalarından ve araba egzozlarından çıkan dumanlar nedeniyle kirlenen bir ortam olarak çizmiştir. Öğrenci "Eyvah Kaçın Pis Duman Geliyor” şeklinde ortamın durumunu karikatürize etmiştir. Bu çizimde hiçbir hayvan ya da bitkinin çizilmemiş olması ve sadece siyah kalemle renksiz bir ortam olarak çizmesi dikkat çekicidir. Aynı öğrenci kağıdın sağ tarafında temiz çevreyi farklı kuşların havada uçtuğu, yerde bazı hayvanların gezindiği ve akarsu içerisinde çok sayıda balığın yüzdüğü bir ortam olarak çizerek tasvir etmiştir. Öğrenci kirli çevreden farklı olarak temiz çevrede evleri, hayvanları ve suyu farklı renklerle boyadığı görülmektedir. Bu resimden de öğrencilerin temiz çevrede farklı canlılara çizimlerinde yer verme eğiliminde oldukları ifade edilebilir. Başka bir öğrenci ise çevrenin kirlenmesine bağlı olarak hayvanların ortamdan kaçtıklarına yönelik bir resim çizmiştir.

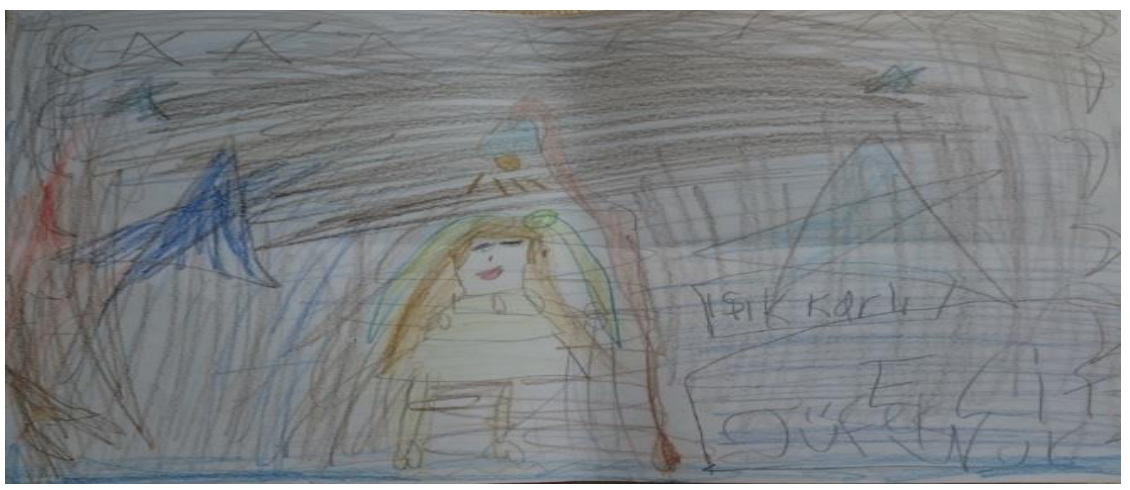

Çizim 9: İlkokul 3. sınıf öğrencisinin ışık kirliliği ile ilgili çizdiği resim.

Çevre kirliliği ile ilgili çizilen resimlerde 1 şık kirliliğine yer veren tek resim 3. sınıf öğrencisi tarafindan çizilmiştir. Öğrenci çizdiği resmi "Bu böyle oturuyor, geceleyin oturup kitap okuyor lambada onu rahatsiz ediyor." şeklinde açıklamaktadır. 


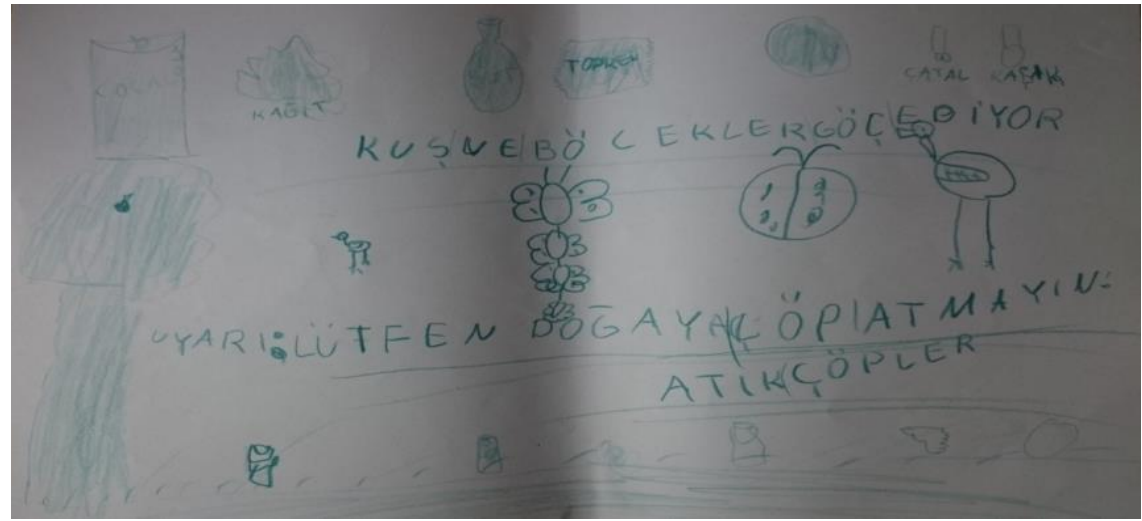

Çizim 10: İlkokul 3. Sınıf öğrencisinin çevre kirliliği ve canlıların verdiği tepki ile ilgili çizdiği resim

Çizim 10'da 3. sınıf öğrencisi çevre duyarlılığına yönelik olarak yapılan "Uyarı: Lütfen Doğaya Çöp Atmayın" şeklindeki uyarıya rağmen farklı atık ve çöplerin atılması sonucunda “Kuşlar Ve Böcekler Göç Ediyor” ifadesiyle kirlenen çevreden canlıların uzaklaştığını çiziminde ifade etmeye çalışmıştır. Öğrenci çevreyi kirleten çöpler olarak teneke (kola), kağıt, süt şişesi, kek ambalajı, çatal, kaşık gibi farklı çöp çeşitlerine çiziminde yer vermiştir.

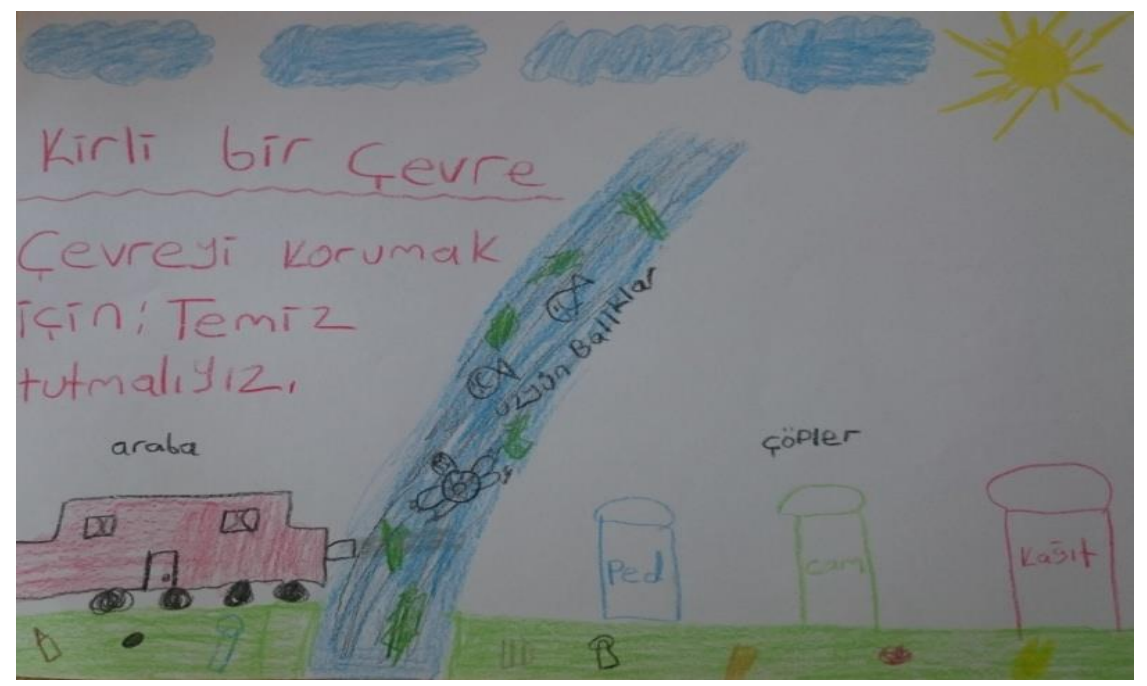

Çizim 11: İlkokul 4. sınıf öğrencisinin çevre kirliliği ve çevre bilincine yönelik çizdiği resim

Özellikle öğrencilere sorulan çevre kirliliğini önlemek için ne yapmak gerekir sorusuna verilen yanıtlar doğrultusunda ögrencilerdeki çevre bilinci tespit edilmiştir. Öğrencilerin büyük bir çoğunluğu çöplerin yere atılmaması konusunda bir bilince sahip oldukları tespit edilmiştir. Çizim 11'de öğrenci kirli bir çevre çizmiş, çöpler ayrı çöp kutuları olmasına rağmen yerlere atılmış, araba egzozundan çıkan dumanlar sebebiyle kirlenen su içerisinde "Üzgün Balıkların" 
olduğu şekilde resmetmiştir. Öğrenci "Çevreyi korumak için; Temiz tutmalıyız" diye yazı yazmıştır.

\section{TARTIŞMA ve SONUÇ}

İlkokul öğrencilerinin çizdiği resimler, resimlerle ilgili yaptıkları açıklamalar dikkate alınarak incelendiğinde çevre kirliliğine sebep olan en önemli etmenin daha çok evsel atıklardan oluşan çöpler olduğu algısına sahip oldukları anlaşılmaktadır. 1. Sınıftan itibaren 4. sınıfa kadar tüm sınıflardaki öğrencilerin çok önemli bir bölümü (\%90 ve üzeri) çevre kirliliğine çöplerin neden olduğu algısına sahip oldukları tespit edilmiştir. Başka bir ifadeyle çevre kirliliğine en fazla çöpler sebep olur algısı sınıf düzeyine göre farklılık göstermemektedir. Öğrenciler çizimlerinde çevre kirliliği olarak çöp kavramından sonra ev ve fabrika bacalarından çıkan dumanların yol açtığı hava kirliliğini resmetmişlerdir. Öğrencilerin çizimlerinde çöp ve hava kirliliğinden sonra su ve deniz kirliliğine yönelik öğelerin de olduğu tespit edilmiştir. Yalnızca 1 öğrenci 1şık kirliliğine çizimlerinde yer verdiği tespit edilmiştir. Yalçınkaya (2013)'nın çevre sorunlarına ilişkin 8. sınıf öğrencilerinin görüşlerinin belirlenmesi amacıyla yaptığı çalışmada öğrencilere çevre sorunları ile ilgili karikatür çizmelerini istemiştir. Öğrencilerin çoğunluğu çizdikleri karikatürlere çevre sorunu olarak birden fazla çevre sorununu yansıttıklarını, bunlar arasında en fazla çöp sorununu, hava kirliliğini, su kirliliğini ve ormanların yok olmasını çizdiklerini tespit etmiştir. Yalçınkaya (2013)'ün yaptığı çalışmanın sonuçları bu araştırmanın bulgularını desteklemektedir. Ayrıca Sadık, Çakan ve Artut (2009) ilköğretim 5. Sınıfta okuyan öğrencilerin çevre sorunlarına yönelik algıları tespit etmek amacıyla yaptıkları çalışmada, öğrencilerin çevre sorunu olarak en fazla hava kirliliğine yönelik çizimler yaptıkları bu sorunu yerlere çöp atma ile ilişkilendirdiği davranış kirliliğinin takip ettiği tespit edilmiştir. Sadık, Çakan ve Artut (2009) öğrencilerin çizimlerinde tespit edilen davranış kirliliğinin yanı sıra su kirliliğinin de çoğunlukla çöp atan insan, su üzerinde yüzen çöp figürleri ve çöp kutusu çizilerek yansıtılması ise çoğunlukla kirlenmenin, bir diğer ifadeyle çöpün çocuklar tarafından çevre sorunu olarak algılandığı şeklinde yorumlamışlardır. $\mathrm{Bu}$ sonuç bu çalışmanın temel bulgusu olan öğrencilerin kirli çevre kavramıyla ilgili en önemli etmenin çöpler olduğu algısıyla ile uyum göstermektedir. Benzer şekilde Yardımcı ve Bağcı Kılıç (2010) ilköğretim 8. Sınıf öğrencileri ile yaptıkları çalışmada öğrencilerin çöp ve egzoz gazlarından kaynaklı hava kirliliği kavramlarının en fazla vurguladıkları çevre sorunu olduğu sonucuna ulaşmışlardır.

Öğrenciler temiz çevrede daha çok çöplerin çöp kutusun atıldığı, ağaçların, çiçeklerin olduğu, gökyüzünde güneş ve mavi bulutların olduğu, farklı ve çok sayıda kuşun uçtuğu, insanların hayvanlara iyi davrandığı ve birbirleriyle oynadıkları, mutlu oldukları resimler çizmişlerdir. Öğrenciler tarafindan çizilen kirli çevre resimleri daha çok siyah beyaz ya da gri ve koyu renkli çizilirken, temiz çevre için farklı renkleri içeren resimler çizdikleri görülmüştür. Çetin (2015) tarafindan 2. ve 3. sınıf öğrencileriyle yapılan çalışmada öğrenci resimleri ve görüşmelerinden elde edilen sonuçlarda öğrencilerin temiz çevreyi yeşil ağaçların, çiçeklerin mavi bir gökyüzünün, sarı bir güneş, doğal renkleriyle bulutların olduğu ortam olarak resmettiklerini tespit etmiştir. Kirli çevreyi ise siyah dumanlarla kaplanmış bir gökyüzü, bu dumanlardan dolayı siyah gözüken bulutların olduğu 
bir ortam olarak çizdiklerini ifade etmiştir. Aynı şekilde Yakışan, Bozkurt ve Demirci (2013) 9., 10., 11., 12., Sınıf lise öğrencileri ile yaptıkları çalışmada öğrencilerin temiz çevre kavramı için güneşli, ormanlık, yeşillik alanlarda gezen, piknik yapan, oyun oynayan çocuklar şeklinde resimler çizdikleri tespit edilmiştir. Çetin (2015) ve Yakışan, Bozkurt ve Demirci (2013)'nin sonuçları bu çalışmanın sonuçlarını desteklemektedir.

Tüm bu verilerden elde edilen sonuçlar tüm sınıflardaki ilkokul öğrencilerinin çevre kirliliği kavramını; ağırlıklı olarak çöp kavramı, daha sonra fabrika, ev bacalarından ve araba egzozlarından çıkan dumanların oluşturduğu hava kirliliği ve bu iki etmene bağlı olarak su ya da denizlerde olan kirlilik olarak algılamaktadırlar. Bu algı sınıflar arasında neredeyse hiç fark etmemektedir. Öğretim programları içerisinde yer verilen diğer çevre sorunlarına çizimlerde nerdeyse hiç yer verilmemektedir. Kısaca öğrencilerin çevre kirliliği ile ilgili çizimlerinden ve açıklamalarından tespit edilen algı verilen çevre eğitiminin öğrencilerin algılarında sınıf düzeyi artmasına rağmen neredeyse hiç değişmediğini göstermektedir. Zira yukarıda da belirtilen ve çalışmanın sonuçlarıyla uyumlu çalışmalarda da gerek ilkokul gerekse diğer öğretim kademelerindeki öğrencilerin çevre sorunları ve çevre kirliliği ile ilgili dar bir bilgi yapısına ve yetersiz bir algıya sahip oldukları ve bilgi yapısı ve algının öğretim düzeyine göre farklılık arz etmediği sonucuna ulaşılmaktadır. Öğrenciler temiz çevrenin elde edilmesi için yerlere ve sulara çöp atılmasının engellenmesi ve kirli duman çıkışının önlenmesiyle sağlanacağı algısına sahiptir. Çevreyi kirleten, kimyasal, radyoaktif, elektromanyetik kirliliklerin yanında, küresel ısınma, iklim değişikliği gibi daha ciddi çevre sorunlarından resimlerinde ve açıklamalarında hiç yer vermedikleri tespit edilmiştir.

Elde edilen bu sonuçlara dayanarak öğrencilere verilen eğitimin teoride kalmaması öğrencilerde bir davranışa dönüşmesi için önlemler alınmalıdır. Çevre kirliliği için çöp kavramının ve kirli dumanların vurgulanmasının yanında diğer çevre kirleticileri ve bunların çevreye olası etkileri de vurgulanmalıdır. Bu konuda öğrencilerin gözlem yapmaları ve farklı belgeseller izlemeleri temin edilmelidir. Ayrıca çevre bilincini geliştirecek projelerde öğrencilere de aktif görevler verilmelidir. 


\section{KAYNAKÇA}

Akbaş, T. (2007), Fen bilgisi öğretmen adaylarında çevre olgusunun araştırılması, Yayınlanmamış Yüksek Lisans Tezi, Atatürk Üniversitesi Fen Bilimleri Enstitüsü, Erzurum.

Çetin, G. (2015). İlkokul Öğrencilerinin Temiz ve Kirli Çevre İle İlgili Görüşleri. Uluslararası Eğitim Bilim ve Teknoloji Dergisi, 1(1), 26-41.

Ersoy, A. F., \& Türkkan, B. (2010). İlköğretim öğrencilerinin çizdikleri karikatürlere yansıttıkları sosyal ve çevresel sorunların incelenmesi. Ĕgitim ve Bilim, 35(156), 96-109.

Ersoy, A., \& Türkkan, B. (2009). İlköğretim öğrencilerinin resimlerinde internet algıs1. Ilköğretim Online, 8(1), 57-73.

Erten, S. (2005). Okul öncesi öğretmen adaylarında çevre dostu davranışların araştırılması. Hacettepe Üniversitesi Ĕ̈itim Fakültesi Dergisi. 28, 91-100.

Karasar, N. (2008). Bilimsel araştırma yöntemi. Ankara: Nobel Yayın Dağıtım.

Leonard, M. (2006). Children's drawings as a methodological tool: Reflections on the develop plus system in northern Ireland. Irish Journal of Sociology, 15(2), 52-66.

MEB (2009). İlköğretim 1, 2 ve 3. sınıflar hayat bilgisi dersi öğretim programı. Ankara. Millı̂ Eğitim Bakanlığı Talim ve Terbiye Kurulu Başkanlığı.

MEB (2013). İlköğretim kurumları (ilkokullar ve ortaokullar) fen bilimleri dersi $(3,4,5,6,7$ ve 8. sinıflar) öğretim programı. Ankara. Millî Eğitim Bakanlığı Talim ve Terbiye Kurulu Başkanlığı.

Özsoy, S., \& Ahi, B. (2014). İlkokul öğrencilerinin geleceğe yönelik çevre algılarının çizdikleri resimler aracılığı ile belirlenmesi. Kuram ve Uygulamada Ĕgitim Bilimleri, 14(4), 1557-1582.

Piperno, F., Di Biassi, S., \& Levi, G. (2007). Evaluation of family drawings of physically and sexually abused children. European Child \& Adolescent Psychiatry, 16(6), 389-397.

Rodari, P. (2007). Science and scientists in the drawings of European children. Journal of Science Communication, 6(3), 1-12.

Sadık, F., Çakan, H. \& Artut, K. (2011). Çocuk resimlerine yansıyan çevre sorunlarının sosyo-ekonomik farklılıklara göre analizi. Illköğretim Online, 10(3):1066-1080.

Selvi, M, (2007). Biyoloji öğretmeni adaylarının çevre kavramları ile ilgili algılamalarının değerlendirilmesi. Doktora Tezi. Gazi Üniversitesi, Eğitim Bilimleri Enstitüsü. Ankara.

Yakışan, M., Bozkurt, B., \& Demirci, T. (2013). Lise öğrencilerinin çevre kavramı ile ilgili bilişsel düzeyleri. XI. Ulusal Ekoloji ve Çevre Kongresi, 01 - 04 Ekim 2013, Samsun. 
Yalçınkaya, E. (2013). İlköğretim 8. sınıf öğrencilerine göre çevre sorunları: nitel bir çalışma. Marmara Coğrafya Dergisi. 27, 416-439.

Yardımcı, E., \& Bağcı Kılıç, G. (2010). Çocukların gözünden çevre ve çevre sorunları. Ilköğretim Online, 9(3), 1122-1136.

Yıldız, K., Sipahioğlu, Ş. \& Yılmaz, M., (2000), Çevre Bilimi, Gündüz Eğitim ve Yayıncılık, Ankara. 


\section{EXTENDED ABSTRACT}

The environmental problems which rapidly increase today continue to affect all worlds intensely. In addition to the insufficiency of the measures to be taken, unconscious behaviors increase the environmental problems more. The impact of the environmental problems on earth, therefore humanity intensely caused the activities to deal with those problems to be accelerated. Together with the legal regulations, the works to make people who are the main factor of the environmental problems aware became more significant, by the time. In order to grow individuals sensitive to the environment, the environmental education starts pre-school time and it is applied at all educational levels. The detection what kind of a perception to be created in students as a result of the environmental education in primary schools is important to review that education.

The aim of this study is to determine the perceptions of the primary school students on the environment through their drawings. For this purpose, a descriptive study was conducted by using the survey model (Karasar, 2008), which aims to describe an existing situation or an event in the way it exists. In order to find out what the perception of 1st, $2 \mathrm{nd}$, 3rd, and 4th grade elementary school students towards environment is like, the sectioning method which is one of the temporal screening approaches and considered to represent various development phases and which aims to determine the studies to be conducted on separate groups at once. Thus, two primary schools in Samsun center were chosen for the study and totally 211 students of which 38 at first grade, 64 at second grade, 59 at third grade and 50 at fourth grade were included in the study. In the study, the students were asked to draw on firstly "Environmental pollution" and then "Clean environment" separately. After that, each student was interviewed to hear their explanations on their drawings and they were asked questions like "What is the environmental pollution in your opinion?", "What are the factors causing environmental pollution?", "How can we prevent the environmental pollution?", and "What should we do for a clean environment?" The paintings of the students were analyzed with reference to their explanations in the interviews.

The students 1 hour was given for the drawings, they would do for the environment and they were enabled to conduct their drawings in two stages. For that purpose, drawing papers were distributed to the students, who were asked to draw on them by using paints. In the one-on-one interviews with students, they were given 2-3 minutes in general to explain the drawings they created after completing both of the drawings. The drawings of each student were separately evaluated. The drawings related to clean environment and polluted environment were separately analyzed. The common conceptions detected in the drawings of the students were categorized. The frequencies of the common conceptions detected, which are related to clean environment and polluted environment in the drawings of 1st, 2nd, 3rd, and 4th grade students were calculated and demonstrated in a table. The drawings that reflected the items detected in the best manner were included and evaluated.

As result of these analyses it was seen that all the paintings include the "domestic trash" causing environmental pollution in all grades. In addition to this environmental problem, it was found that air pollution and low number of students 
with compare to first two, considered the sea pollution within the scope of the water pollution. Other environmental problems had always never been referred in the drawings. The students made paintings on clean environment where there is no trash with rivers, trees and green. As a result, it is seen that the primary school students have very limited knowledge of environmental pollution; they think that the trashes are the main reason of the environmental pollution and the pollution can be prevented if the trashes are collected regularly.

The findings obtained from the drawings and explanations of the elementary school students regarding environmental pollution suggests that the environmental education given to the students increased the perception level of students at the classroom level, however, their perception did not change at all. In the similar studies previously carried out, it was found out that not only at the elementary school level but at all school levels students had narrow knowledge and inadequate perception on environmental problems and environmental pollution and the level of knowledge or perception did not vary based on the education level of the person. The students have the perception that a clean environment can be obtained by preventing people from polluting the streets and waters or preventing dirty smoke evolution. It was observed that the students did not include chemical, radioactive, electromagnetic pollutants or more serious environmental problems such as global warming or climate changes, in their drawings at all.

According to these findings, the education given to the students should not be limited to the theoretical framework; necessary measures should be taken in order to turn this theory into a behavior in students. We should not only focus on waste or dirty smoke but also other pollutants and their impact on the environment. The students should be enabled to observe or watch different documentaries on such issues. Moreover, active responsibilities should be granted to the students in the projects that will increase environmental awareness. 